\title{
Lesson Learned Peralihan Mata Pencaharian Masyarakat Sebagai Ketahanan Terhadap Perubahan Iklim Kelurahan Mangunharjo
}

\author{
Tiara Citra Septiana ${ }^{1}$ \\ PT Bank Negara Indonesia Syariah, \\ Kabupaten Kudus, Indonesia
}

\begin{abstract}
Abstrak: Adanya bencana banjir, kenaikan muka air laut, serta abrasi menyebabkan besarnya kehilangan lahan pertanian yang dimiliki oleh masyarakat. Selain itu, tambak juga menjadi salah satu sumber penghidupan masyarakt. Jika tambak tidak dapat lagi dipertahankan, maka akan menyebabkan suatu masalah sosial-ekonomi di masyarakat. Oleh sebab itu, dibutuhkan upaya adaptasi untuk meneysuaikan diri dengan perubahan kondisi alam yang disebabkan fenomena perubahan iklim. Salah satu bentuk adaptasi dilakukan oleh masyarakat Kelurahan Mangunharjo dengan merubah mata pencaharian mereka. Tujuan dari penelitian ini adalah untuk menemukan pembelajaran yang dapat diperoleh dari transisi mata pencaharian masyarakat di sana yang dapat direplikasi di wilayah lain. Hasil dari penelitian ini dibedakan berdasarkan pelaku individu dan kelompok. Lalu jika dilihat berdasarkan proses pembelajarannya, dapat dibedakan menjadi pembelajaran yang diperoleh sambil dilakukan dan pembelajaran yang diperoleh melalui interaksi. Kendala yang masih terjadi terdapat pada proses transfer pengetahuan. Banyak orang yang memilih mata pencaharian baru yang tidak menuntut tingkat pendidikan dan keterampilan yang tinggi karena mereka tidak memiliki hal tersebut.
\end{abstract}

Kata Kunci: masyarakat, perubahan iklim, perubahan mata pencaharian

\begin{abstract}
The existence of catastrophic flooding, sea level rise, with the abrasion causes severe loss of farm land owned by the community. In fact, fishponds have been gotten a source of community life. If the pond area can no longer be processed, it will lead to socioeconomic problems of society. Therefore, it required an effort of adaptation to adjust to changing environmental conditions due to the occurrence of the phenomenon of climate change. One of the adaptations made Kelurahan Mangunharjo's community is to make the trasition livelihood. In the transition process undertaken by livelihood there is definitely a learning community that is used as a stock of knowledge to switch to a new job.Further, the goal of this study is to find on lesson learn that can be taken from the transition in the Kelurahan Mangunharjo's livelihoods that can be used for replication in other areas. The result of this study there are the distinguished based on the offender, which the offender learning process in the Kelurahan Mangunharjo can be divided into two parties, including individuals and groups. While, if it differentiated based on the learning process that is owned by Kelurahan Mangunharjo's community, then there are two types of processes used, among others, through learning by doing and learning by interaction. Obstacles that still occurs today lies in the process of transfer of knowledge possessed by the community.Most people
\end{abstract}

\footnotetext{
${ }^{1}$ Korespondensi Penulis: PT Bank Negara Indonesia Syariah, Kabupaten Kudus Email: tiaracitraseptiana@yahoo.co.id
} 


\section{Lesson Learned Peralihan Mata Pencaharian Masyarakat Sebagai Ketahanan Terhadap Perubahan Iklim}

move to jobs that do not reach the level of education and skill levels are high,because they have a low knowledge and skill.

Keywords: climate change, community, livelihood change

\section{Pendahuluan}

Keberadaan fenomena perubahan iklim global tidak lagi dapat dipertentangkan melihat berbagai bukti penelitian yang dikemukakan oleh para ahli. Laporan ke-4 yang dipublikasikan oleh Kelompok Kerja II International Panel on Climate Change (IPCC) pada bulan April 2007 mengungkapkan mengenai ancaman perubahan iklim global terhadap keberlangsungan hidup manusia, dimana perubahan iklim diyakini telah mengakibatkan terjadinya peningkatan persipitasi di berbagai belahan dunia (IPCC dalam Few, 2003 : 45). Peningkatan persipitasi tersebut, yang ditandai oleh adanya peningkatan intensitas curah hujan, kenaikan muka air laut (sea level rise), dan munculnya badai ekstrim, pada akhirnya memicu terjadinya peningkatan frekuensi banjir dan terjadinya rob di wilayah pesisir. Akan tetapi, selain dikarenakan oleh fenomena perubahan iklim itu sendiri, bencana banjir yang terjadi juga tidak terlepas dari campur tangan manusia. Tingginya kepadatan penduduk maupun kepadatan bangunan, sistem drainase yang tidak memadai, dan faktor-faktor lainnya pun ikut memperluas cakupan wilayah yang terkena bencana banjir. Hal ini tentu saja mengakibatkan kerugian yang tidak sedikit bagi masyarakat, baik hilangnya nyawa maupun lenyapnya berbagai barang-barang berharga. Jika dilihat dari aspek fisik maupun aspek non-fisik, bencana banjir telah menyapu sarana dan prasarana, melumpuhkan sistem perekonomian, mengurangi produktivitas kerja masyarakat, mengganggu kesehatan serta keberlangsungan pendidikan masyarakat, dan lain sebagainya. Begitu pula terjadinya rob, dimana selain disebabkan oleh faktor kenaikan muka air laut, bencana rob juga semakin diperparah dengan adanya faktor manusia dalam melakukan kerusakan lingkungan.

Asian Cities Climate Change Resilience Network (ACCCRN) sebagai salah satu lembaga yang memiliki tujuan untuk membangun ketahanan masyarakat terhadap perubahan iklim di kota-kota Asia, menyatakan bahwa Semarang sebagai salah satu kota yang terkena dampak dari perubahan iklim yang mengalami kerentanan (Rockfeller Foundation.org). Hal ini dikarenakan letak Kota Semarang yang berbatasan langsung dengan Laut Jawa. Sebagai wilayah pesisir yang didukung oleh keberadaan pelabuhan Tanjung Mas dan berbagai sarana prasarana yang lengkap dan memadai, kota ini memiliki fungsi strategis sebagai pintu gerbang ekspor dan impor berskala lokal, nasional, maupun internasional. Hal tersebut tentu saja mendorong terjadinya peningkatan pertumbuhan ekonomi yang kemudian menarik banyak orang untuk mengadu keberuntungan di Kota Semarang. Akan tetapi, sama dengan kota-kota besar lain di Indonesia, Kota Semarang juga tidak terlepas dari bencana yang diakibatkan oleh adanya fenomena perubahan iklim global, misalnya bencana banjir, rob, badai, angin topan, dan sebagainya. Pernyataan adanya badai dan intensitas curah hujan yang tinggi di wilayah pesisir Kota Semarang diberikan oleh Kepala Seksi Data dan Informasi Badan Meteorologi, Klimatologi, dan Geofisika (BMKG) Jawa Tengah, Evi Lutiviati, yang menyebutkan bahwa kecepatan angin di Kota Semarang dalam sepekan berkisar 30 kilometer per jam dan bahkan mampu mencapai 40 kilometer per jam. Tingginya kecepatan angin tersebut mengakibatkan gelombang tinggi di laut. Selain itu, cuaca ekstrim di Kota Semarang yang disertai pula dengan hujan lebat dan angin kencang masih akan terjadi hingga Februari 2011. Sementara, intensitas hujan rata-rata 20-50 milimeter per hari, tetapi masih ada kemungkinan curah hujan mencapai 100 milimeter per hari (Harian Kompas, 12 Januari 2011). Intensitas curah hujan yang tergolong tinggi tersebut dapat menyebabkan terjadinya 
bencana banjir di wilayah pesisir. Selain itu, masih terjadi pula kenaikan muka air laut Kota Semarang sebesar 0,8 sentimeter per tahunnya. Akibatnya, masyarakat yang tinggal di wilayah pesisir berpotensi untuk mengalami kerugian yang besar, sehingga meningkatkan kerentanan ekonomi dan sosial. Kerentanan sektor ekonomi, antara lain berdampak pada hilangnya pendapatan masyarakat sehari-hari karena lumpuhnya sistem perekonomian yang ada. Adapun, dari sektor sosial potensi kerugian berupa penurunan kesehatan masyarakat dan anak-anak yang tidak dapat bersekolah selama beberapa hari karena sekolah mereka terendam air.

Terkait dengan perubahan iklim yang terjadi di Kota Semarang, ACCRN yang bekerjasama dengan Mercy Corps menyatakan bahwa Mangunharjo merupakan salah satu kelurahan di Kecamatan Tugu yang mengalami kerentanan akibat terjadinya bencana banjir (ACCRN dan Mercy Corps, 2010). Hal ini dikarenakan lokasi kelurahan tersebut berada di tepi laut, mengalami abrasi, bencana banjir, dan semakin diperparah oleh kenaikan muka air laut. Bahkan, pada November 2010 kemarin, masyarakat Kelurahan Mangunharjo terkena bencana banjir hingga mencapai ketinggian 2 meter akibat jebolnya tanggul Sungai Beringin (Media Indonesia.com, 11 November 2010). Secara ekonomi, bencana banjir tersebut berdampak pada keberlanjutan hidup masyarakat yang tinggal di Kelurahan Mangunharjo. Selama ini, masyarakat Mangunharjo memiliki mata pencaharian yang tergantung pada kondisi alam di sekitarnya, yaitu sebagai petani tambak. Adanya bencana banjir, kenaikan muka air laut, yang ditambah dengan abrasi parah menyebabkan hilangnya lahan tambak yang dimiliki oleh masyarakat. Padahal, lahan tambak telah menjadi sumber kehidupan masyarakat. Jika lahan tambak tersebut tidak dapat lagi diolah, maka hal ini akan menyebabkan terjadinya permasalahan sosial ekonomi masyarakat. Oleh karena itu, diperlukan suatu upaya adaptasi untuk menyesuaikan diri dengan kondisi perubahan lingkungan akibat terjadinya fenomena perubahan iklim. Salah satu adaptasi yang dilakukan masyarakat Kelurahan Mangunharjo adalah dengan melakukan peralihan mata pencaharian. Dengan adanya peralihan mata pencaharian, diharapkan masyarakat akan dapat membangun ketahanan sosial dan ekonomi demi mempertahankan keberlangsungan hidup mereka.

Mata pencaharian berhubungan erat dengan pendapatan sebagai faktor utama dalam menunjang keberlanjutan hidup masyarakat. Tanpa memiliki mata pencaharian tertentu, masyarakat tidak akan mampu memenuhi kebutuhan hidupnya, tidak terkecuali bagi masyarakat yang tinggal di Kelurahan Mangunharjo. Sekitar sepuluh tahun yang lalu, masyarakat masih banyak yang memilih profesi sebagai petani tambak. Akan tetapi, adanya bencana banjir yang terjadi setiap tahun dengan disertai oleh abrasi parah dan kenaikan muka air laut menyebabkan hilangnya lahan tambak dan rusaknya kawasan permukiman dan fasilitas usaha masyarakat.

Berdasarkan hasil FGD di Kelurahan Mangunharjo pada tahun 1998, masyarakat menyatakan bahwa sebagian besar lahan tambak mereka habis dan dalam sekejap berubah menjadi pantai (Dokumen Masterplan Drainase Kota Semarang). Oleh karena itu, untuk beradaptasi dari adanya bencana banjir tersebut, pada akhirnya masyarakat Kelurahan Mangunharjo memutuskan untuk melakukan peralihan mata pencaharian kepada bentuk mata pencaharian lain dan sesuai dengan kemampuan yang mereka miliki. Peralihan tersebut sangat penting untuk dilakukan mengingat lahan tambak yang masyarakat miliki telah hancur atau mengalami penurunan produktivitas. Hal ini dialami oleh salah satu masyarakat Kelurahan Mangunharjo. Pada tahun 2002, dia kehilangan 2,5 hektar tambaknya yang bisa menghasilkan sekitar Rp 8 juta per empat bulan. Oleh karena itu, dia kemudian beradaptasi dengan dengan melakukan peralihan mata pencaharian, yaitu dengan ikut menjual bibit-bibit mangrove yang dibeli oleh perusahaan, universitas, LSM, dan petani tambak, dengan perolehan pendapatan sekitar Rp 800.000 per bulan. Apabila dibandingkan dengan perolehan pendapatannya yang dahulu pada saat lahan tambaknya 
belum hilang, pendapatan tersebut sangat jauh berkurang. Selain dikarenakan oleh bencana banjir, lahan tambak juga dapat pula mengalami penurunan kadar unsur hara akibat penggunaan zat-zat kimia pada makanan serta obat-obatan untuk tambak, disertai pula dengan adanya limbah, baik limbah pabrik maupun rumah tangga yang dibuang ke sungai, masuk ke laut dan akhirnya masuk ke dalam lahan tambak.

Peralihan mata pencaharian yang dialami oleh masyarakat membawa dampak besar terhadap keberlangsungan kondisi masyarakat secara keseluruhan. Jika semula masyarakat Kelurahan Mangunharjo memiliki usaha sendiri dengan menjadi petani tambak dan memperoleh penghasilan yang cukup tinggi, maka sejak lahan tambak mereka hancur dan tidak lagi subur, mereka kemudian beralih bekerja di sektor non-pertanian, misalnya dengan menjadi buruh. Sebagai buruh, masyarakat tidak mempunyai pendapatan yang berasal dari upaya mereka sendiri melainkan cenderung bergantung kepada orang lain, sehingga mereka mengalami penurunan pendapatan secara drastis. Hal ini ditandai dengan pendapatan masyarakat yang menurun secara drastis dari kisaran Rp 500.000 per hari menjadi hanya berkisar Rp 25.000 - Rp 50.000 per hari. Bahkan, nilai kerugian usaha tambak akibat terjadinya bencana banjir di Kelurahan Mangunharjo rata-rata Rp 4.209.000, jauh lebih tinggi dibandingkan dengan Kelurahan Tanjung Mas yang merugi Rp 208.333 atau Kelurahan Trimulyo yang rata-rata hanya mengalami kerugian sebesar Rp 288.250 (Dokumen Masterplan Drainase Kota Semarang).

Pendapatan masyarakat Mangunharjo yang cenderung rendah disertai dengan kerugian yang dialami membawa efek domino bagi aspek lain, seperti ketidakmampuan masyarakat dalam memenuhi kebutuhan hidup sehari-hari, mendapatkan akses di bidang pada sektor kesehatan dan pendidikan, dan lain sebagainya. Kajian ini selanjutnya bertujuan untuk digunakan sebagai temuan mengenai pembelajaran yang dapat diambil dari adanya peralihan mata pencaharian di Kelurahan Mangunharjo yang dapat digunakan untuk melakukan replikasi di daerah lain.

Di dalam proses peralihan mata pencaharian yang dilakukan oleh masyarakat pasti terdapat suatu pembelajaran yang digunakan sebagai bekal pengetahuan untuk beralih melakukan pekerjaan yang baru. Proses pembelajaran ini dapat dikatakan sebagai proses penyebaran pengetahuan yang telah ada sebelumnya maupun proses penyebaran pengetahuan yang baru ditemukan. Proses pembelajaran ini dapat dipelajari oleh individu maupun kelompok melalui berbagai pendidikan formal maupun pelatihan atau dapat pula melalui pengalaman yang selama ini diperoleh dan interaksi dengan pihak lain (OECD, 2001: 13).

Pelaku proses pembelajaran dapat dibedakan menjadi dua pihak, yaitu individu dan kelompok. Dalam melakukan proses pembelajaran, individu memperoleh pembelajaran pertama kali berasal dari keluarga. Selanjutnya, pembelajaran bagi masing-masing individu ini dapat diperoleh dari pendidikan, baik formal maupun informal. Dalam hal ini, pendidikan formal terdiri dari sekolah, akademi, universitas, praktek kerja lapangan, serta pelatihan kerja. Sedangkan, pendidikan informal ini lebih ditekankan pada pembelajaran yang didapatkan berdasarkan pengalaman yang diperoleh oleh individu pada saat melakukan pekerjaannya yang baru. Proses pembelajaran yang diperoleh individu ini berupa knowledge capital (OECD, 2001: 14). Sementara, pada pembelajaran yang dilakukan secara berkelompok berasal dari pengetahuan yang telah ada dan dapat pula bekerja bersama-sama untuk menghasilkan suatu pengetahuan yang baru. Kerjasama yang dilakukan ini dapat dilakukan antarindividu dalam kelompok maupun interaksi antarkelompok untuk mencapai tujuan bersama. Manfaat dari pembelajaran yang dilakukan dalam kelompok adalah masing-masing individu dalam kelompok dapat belajar dan meningkatkan kemampuan yang ada dalam diri mereka. Kemampuan yang ada di dalam individu tersebut diasah melalui interaksi dalam kelompok, sehingga akan diperoleh pengetahuan yang baru (OECD, 2001: 17). 
Apabila dilihat berdasarkan proses pembelajaran yang dialami masyarakat, maka ada dua macam cara yang dapat digunakan, yaitu melalui learning by doing dan learning by interaction. Pertama, learning by doing merupakan suatu proses pembelajaran pengetahuan yang diperoleh oleh individu maupun kelompok melalui praktek secara langsung di lapangan. Pada intinya, proses pembelajaran melalui tindakan ini jelas menitikberatkan pada banyaknya pengalaman yang dimiliki oleh individu/ kelompok. Jadi, learning by doing tidak didasarkan pada pendidikan formal maupun pelatihan yang dimiliki, tetapi lebih kepada pengalaman yang selama ini didapatkan yang secara langsung dipraktekkan dalam bentuk pengetahuan, kemampuan, dan keterampilan di lapangan dengan tujuan untuk mengatasi permasalahan. Oleh karena tidak berbasis pada pendidikan formal maupun pelatihan, maka learning by doing ini cukup tepat apabila dilakukan oleh individu/ kelompok yang pada umumnya tidak memiliki biaya untuk meneneruskan pendidikan dan pelatihannya. Kedua, learning by interaction merupakan proses pembelajaran yang diperoleh melalui interaksi sejumlah individu. Adanya interaksi sosial antarindividu dalam bentuk saling bertukar informasi akan dapat membuat individu memiliki pandangan untuk menyelesaikan permasalahan yang ada di lapangan, menghadapi tantangan perubahan yang terjadi, serta pada akhirnya akan dapat meningkatkan produktivitas mereka. Dalam hal ini, pembelajaran berarti tidak hanya tergantung dari kemampuan dan tingginya pendidikan yang dimiliki, tetapi juga melalui interaksi sosial. Learning by interaction ini penting dilakukan apabila orang merasa bahwa diri mereka lemah dalam menggali potensi pembelajaran melalui learning by doing (OECD, 2001: 16).

\section{Metodologi}

Metode yang digunakan dalam penelitian ini adalah metode deskriptif kualitatif, karena lebih melihat pada proses-proses yang terjadi dalam peralihan mata pencaharian. Penelitian ini memerlukan keterlibatan langsung dari peneliti dalam penggalian informasi dari para narasumber. Dengan penelitian kualitatif, maka diharapkan dapat menjawab dan menjelaskan pertanyaan penelitian, karena data-data secara kuantitatif kurang mendukung untuk menjelaskan kondisi tersebut, terutama kondisi sosial ekonomi masyarakat. Adapun, pelaksanaan penelitian dilakukan di dalam beberapa tahapan, antara lain Tahapan pra survei merupakan tahapan persiapan penelitian yang dilakukan dengan mematangkan konsep, menyusun rencana survei, dimana dalam hal ini meliputi penyusunan kebutuhan data beserta sumbernya, menentukan tokoh kunci, menyusun jadwal survei, selain perencanaan yang dilakukan dalam tahapan ini adalah mempersiapkan perijinan dan instrumen survei yang dipakai di lapangan, yaitu kisi-kisi wawancara, perekam, kamera, dan alat tulis.

\section{Tahapan Pengumpulan Data}

Pada tahapan pengumpulan data ini, data yang diperoleh berupa data primer dan data sekunder. Data sekunder diambil dari data monografi Kelurahan Mangunharjo serta data yang berasal dari instansi pemerintah, sedangkan data primer diperoleh dari hasil observasi lapangan dan wawancara yang dilakukan secara mendalam. Observasi lapangan merupakan salah satu teknik pengumpulan data primer yang digunakan dalam penelitian untuk memperoleh gambaran yang jelas dan lengkap mengenai permasalahan yang menjadi fokus diadakannya penelitian ini. Observasi lapangan ini dilakukan dengan cara datang dan melihat secara langsung gambaran Kelurahan Mangunharjo, yang disertai dengan pengambilan foto dokumentasi untuk membantu mendeskripsikan kondisi eksisting wilayah studi. Sedangkan, wawancara secara mendalam digunakan untuk mengetahui 
informasi yang dimiliki oleh narasumber secara langsung pada wilayah studi dengan tujuan untuk mendapatkan gambaran lengkap mengenai objek penelitian serta mendapatkan kenyataan yang terdapat di lapangan, sehingga informasi dapat tergali dengan optimal. Adapun, informasi yang didapatkan dari hasil wawancara ini, meliputi kerentanan masyarakat akibat bencana banjir, proses pembelajaran dalam peralihan mata pencaharian masyarakat, faktor-faktor yang mempengaruhi preferensi masyarakat untuk beralih mata pencaharian, serta bagaimana ketahanan sosial ekonomi masyarakat akibat peralihan mata pencaharian tersebut.

Wawancara dilakukan dengan teknik bola salju (snow ball) yang dimulai dari responden yang menjadi kunci informasi, yaitu proses kronologis perkembangan proses peralihan mata pencaharian masyarakat. Selanjutnya, peneliti meminta rekomendasi pada responden kunci tersebut mengenai siapa saja orang yang cocok menjadi respoden yang menguasai objek penelitian. Wawancara selanjutnya dilakukan peneliti untuk mendapatkan gambaran mengenai perkembangan proses peralihan mata pencaharian, preferensi masyarakat dalam memilih lapangan pekerjaan pengganti, serta ketahanan masyarakat dari proses peralihan mata pencaharian tersebut. Setelah mendapatkan informasi dari seorang responden yang cukup mendalam, maka peneliti mewawancarai responden lain dengan menanyakan hal yang sama pada responden untuk kesekian kali hingga tidak ada informasi baru lagi yang didapatkan. Teknik wawancara ini dilakukan untuk mengetahui dan memperluas informasi, sehingga informasi yang didapatkan akan lebih mendetail.

Tidak semua masyarakat Kelurahan Mangunharjo diwawancarai. Teknik sampling yang dipilih dalam penelitian ini adalah purposive sampling atau sampel bertujuan dengan pertimbangan sebagai berikut.

a. Memudahkan peneliti untuk mendapatkan data yang sesuai dengan kebutuhan.

b. Memungkinkan peneliti untuk memperoleh informasi yang reliabel dan detail.

c. Penelitian ini tidak mengutamakan banyaknya jumlah narasumber, melainkan responden dipilih yang memberikan informasi yang benar, sehingga jumlah tidak diutamakan.

d. Penghematan waktu dan biaya, karena hanya orang tertentu yang dipilih untuk menjadi responden.

\section{Tahapan Kompilasi dan Reduksi Data}

Setelah data-data yang dibutuhkan terkumpul, selanjutnya dilakukan kompilasi data melalui beberapa tahapan, antara lain pengkodean data, reduksi data

a. Pengkodean data

Tujuan dari tahapan pengkodean data adalah untuk mempermudah interpretasi data dan penggunaan data yang telah didapatkan.

b. Reduksi data

Dalam proses wawancara, seringkali responden menceritakan banyak hal yang tidak berkaitan dan tidak diperlukan dalam penelitian. Oleh karena itu, langkah awal yang dilakukan pada saat pengkodean adalah dengan membuang atau mereduksi data yang tidak sesuai dengan tujuan penelitian.

c. Penyajian data

Penyajian data kualitatif dalam penelitian ini dilakukan dengan cara mendeskripsikan data hasil wawancara maupun observasi dengan mengambil hasil cuplikan wawancara yang sesuai dengan tujuan penelitian yang dilakukan. Hasil cuplikan wawancara tersebut kemudian dimasukkan ke dalam tabel pengkodean data. Tabel pengkodean data ini digunakan dengan tujuan agar informasi yang dikutip untuk memperkuat pernyataan analisis peneliti terstruktur dengan jelas sesuai dengan hasil wawancara yang telah dilakukan. 
d. Verifikasi data

Teknik verifikasi data ditempuh melalui triangulasi data dengan meng-crosscheck kembali informasi yang didapat antara suatu sumber dengan sumber informasi lainnya maupun antara teknik analisis yang satu dengan analisis lainnya. Cara verifikasi data tersebut dilakukan dengan membandingkan antara hasil wawancara yang diperoleh dengan kenyataan yang ada di lapangan. Selain itu, dapat pula ditempuh dengan melihat kemiripan jawaban antar responden. Apabila terdapat perbedaan jawaban dari responden, maka peneliti akan memberikan pertanyaan tambahan dengan tujuan untuk memperoleh keterangan lebih lanjut.

\section{Tahapan Analisis}

Setelah tahapan pengolahan data telah selesai dilakukan, maka tahapan selanjutnya yang dilakukan adalah tahapan analisis data. Tahap analisis merupakan tahapan utama dalam penelitian ini. Data yang telah melalui proses kodenisasi, reduksi, dan verifikasi akan diinterpretasikan dan distrukturkan untuk mengambil sebuah konsep atau kesimpulan dari temuan penelitian. Tahapan analisis merupakan tahapan utama dalam penelitian ini, dimana data yang telah melalui proses kodenisasi, reduksi, dan verifikasi akan diinterpretasikan dan distrukturkan untuk mengambil sebuah konsep atau kesimpulan dari temuan penelitian.

Teknik analisis kualitatif yang dimaksudkan dalam penelitian ini adalah analisis deskriptif kualitatif. Analisis deskriptif kualitatif ini digunakan untuk menganalisis data dari hasil wawancara dan observasi lapangan untuk menggambarkan kondisi detail di wilayah studi, sehingga dapat disajikan informasi yang sistematis, sehingga dapat lebih mudah dipahami dan dimengerti. Teknik analisis kualitatif deskriptif ini ditujukan untuk memberikan gambaran mengenai fakta yang terdapat pada wilayah studi, meliputi proses pembelajaran masyarakat, faktor yang mempengaruhi preferensi masyarakat, serta tingkat ketahanan masyarakat dalam menghadapi bencana banjir.

Analisis perkembangan proses pembelajaran masyarakat dalam upaya peralihan mata pencaharian masyarakat. Analisis perkembangan proses pembelajaran masyarakat Kelurahan Mangunharjo ini dilakukan dengan tujuan untuk mengenali bagaimana kronologis proses pembelajaran masyarakat terhadap mata pencahariannya yang selama ini digeluti. Dalam analisis ini, peneliti berusaha mengidentifikasi latar belakang terjadinya peralihan mata pencaharian, pihak yang melakukan proses pembelajaran, apakah masingmasing individu ataukah proses pembelajaran dilakukan secara kelompok, dan kemudian perlu pula dikaji mengenai bagaimana proses pembelajaran tersebut dapat dilakukan, apakah melalui pengalaman diri sendiri ataukah interaksi yang dilakukan antarindividu dalam kelompok maupun interaksi yang dilakukan dengan pihak di luar kelompok. Teknik analisis yang digunakan adalah analisis deskriptif kualitatif. 


\section{Temuan Studi}

Ketika masyarakat di Kelurahan Mangunharjo memutuskan untuk menggeluti mata pencaharian tertentu, baik pada saat tetap bertahan sebagai petani tambak maupun ketika memutuskan untuk beralih mata pencaharian lainnya, pasti akan terdapat suatu pembelajaran (lesson learned) yang digunakan oleh masyarakat sebagai bekal pengetahuan dalam menggeluti mata pencaharian tersebut. Proses pembelajaran tersebut dapat dikatakan sebagai proses penyebaran pengetahuan yang dimiliki oleh masyarakat Kelurahan Mangunharjo, baik yang dilakukan secara individu maupun kelompok (lihat Gambar 1)

Adapun, pembelajaran yang terdapat di Kelurahan Mangunharjo itu sendiri dapat dibedakan berdasarkan dua karakteristik, yaitu berdasarkan atas pelaku dan proses pembelajaran tersebut. Berikut ini merupakan diagram pembelajaran (lesson learned) masyarakat Kelurahan Mangunharjo pada mata pencaharian yang mereka geluti yang dirinci berdasarkan atas jenis pelaku dan proses pembelajaran.

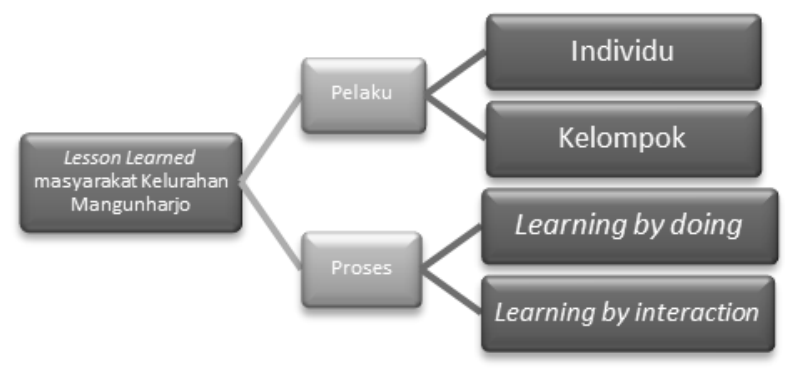

\section{Gambar 1. Diagram Pembelajaran (Lesson Learned) Masyarakat Kelurahan Mangunharjo dalam Menggeluti Mata Pencaharian}

Apabila dibedakan berdasarkan atas pelaku, maka pelaku proses pembelajaran di Kelurahan Mangunharjo dapat dibagi ke dalam dua pihak, meliputi individu dan kelompok. Dalam melakukan pembelajaran, masyarakat di Kelurahan Mangunharjo pada umumnya mendapatkan pengetahuan mengenai mata pencahariannya dari orang tua dan keluarga. Selanjutnya, pada umumnya masyarakat memperoleh pengetahuannya dari pengalaman yang dimiliki selama menggeluti pekerjaan yang dimiliki serta adanya pelatihan yang diadakan oleh pihak luar, seperti dari instansi pemerintah maupun perguruan tinggi. Sementara, pembelajaran yang dilakukan secara berkelompok berasal dari pelatihan yang diadakan dalam kelompok serta adanya diskusi yang dilakukan secara bersama-sama dalam pertemuan. Pertemuan tersebut biasanya diadakan untuk membahas permasalahan dan solusi tertentu yang akan diambil bersama, sehingga masing-masing individu yang berada dalam kelompok tersebut dapat meningkatkan kemampuan dalam diri mereka. Jadi, peningkatan kemampuan diri masing-masing masyarakat tersebut dapat diperoleh dari interaksi yang dilakukan antarmasyarakat itu sendiri.

Apabila dibedakan berdasarkan proses pembelajaran yang dimiliki oleh masyarakat Kelurahan Mangunharjo, maka ada dua jenis proses yang digunakan, antara lain melalui learning by doing dan learning by interaction. Pertama, berbicara mengenai learning by doing, masyarakat Kelurahan Mangunharjo memperoleh pengetahuannya berdasarkan pengalaman langsung di lapangan dengan cara mengamati kondisi yang berada di lapangan dan kemudian mempelajarinya untuk digunakan dalam pengelolaan lahan tambak. Kedua, learning by interaction juga dilakukan oleh masyarakat Kelurahan Mangunharjo melalui diskusi dan saling tukar menukar informasi di lapangan. Selain itu, masyarakat memperoleh pengetahuan yang dimiliki melalui pelatihan, penyuluhan, 
maupun studi banding yang dilakukan oleh pemerintah bekerjasama dengan masyarakat itu sendiri.

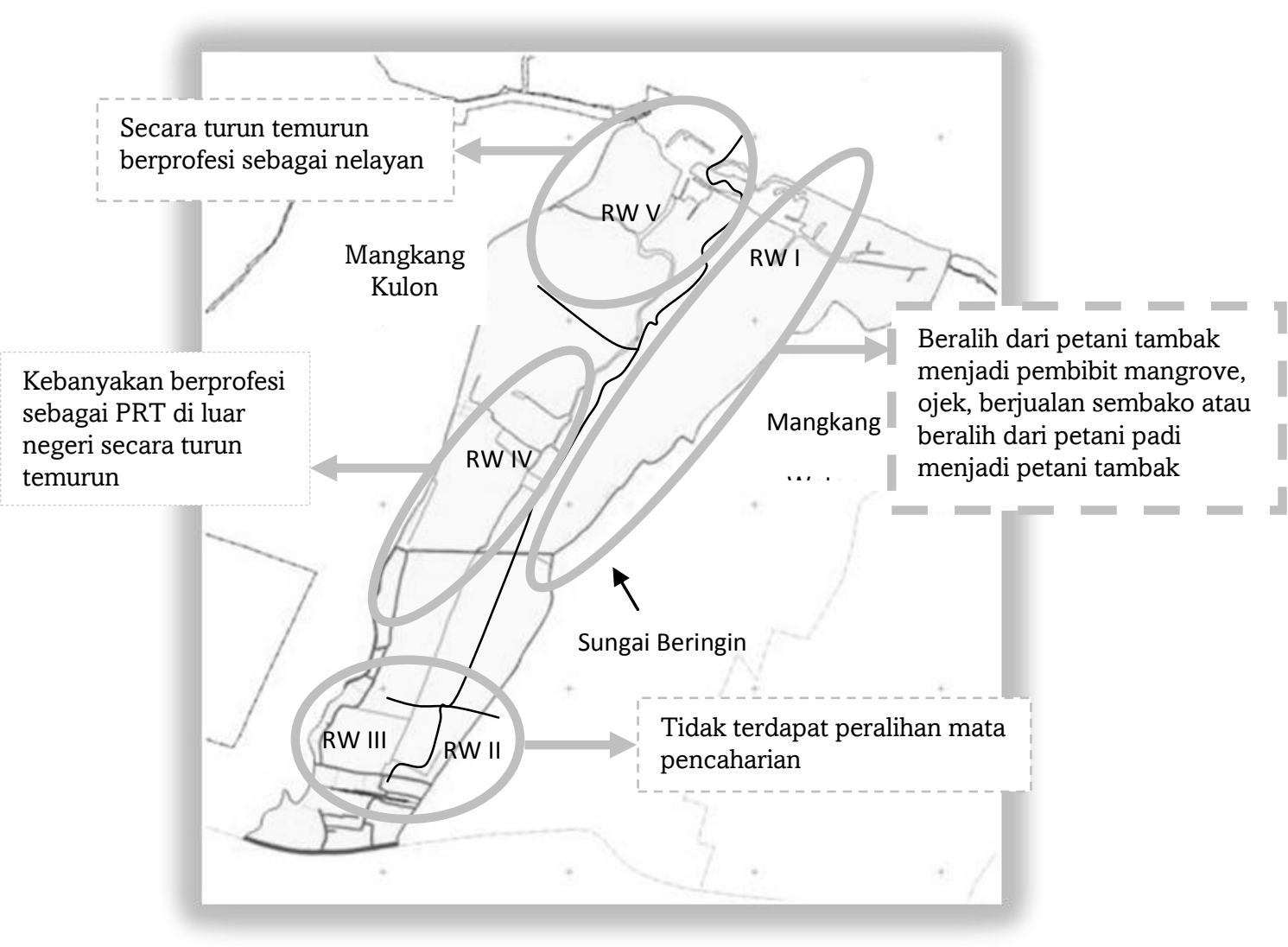

Gambar 2. Pola Peralihan Mata Pencaharian Masyarakat Kelurahan Mangunharjo

\section{Masyrakat yang Tetap Berada di Jalur Petani Tambak Hingga Sekarang}

Pertama kali, sebelum tahun 1970-an, petani tambak di Kelurahan Mangunharjo pada umumnya memperoleh pengetahuan untuk mengolah dan mengelola tambaknya dari orang tua atau keluarganya. Jadi, pengetahuan tersebut diperoleh melalui garis keturunan yang diwariskan secara turun temurun. Hal tersebut terjadi secara alamiah, karena lingkungan di sekitar Kelurahan Mangunharjo memang selalu berhubungan dengan pengelolaan lahan tambak. Selain itu, kondisi lahan tambak masih sangat memungkinkan digunakan untuk bertani tambak, dimana keuntungan yang diperoleh dari lahan tambak tersebut dapat digunakan untuk mencukupi kebutuhan hidup sehari-hari.

Oleh karena selalu berkecimpung di sektor pertambakan, maka masyarakat secara tidak langsung ikut mengetahui berbagai seluk beluk tentang bagaimana cara mengelola tambak. Bahkan, apabila orang tuanya bukan petambak sekalipun, pengetahuan tentang pengelolaan lahan tambak diperoleh berdasarkan pengalaman di lapangan. Dalam hal ini, masyarakat dapat mengelola tambak dengan baik, padahal tidak membaca buku maupun masuk ke sekolah khusus yang mempelajari pertambakan. Lahan tambak milik masyarakat dikelola secara tradisional dan tidak mengeksploitasi lahan, sehingga kondisi lingkungan tetap terjaga. Selain itu, berdasarkan atas hasil wawancara, ketika belum terjadi penurunan kualitas produktivitas lahan tambak seperti pada saat ini, cara pengelolaan tambak tersebut 
masih tergolong cukup mudah, sehingga berbagai pelatihan pun belum terlalu diperlukan oleh masyarakat.

Kemudian, terdapat satu organisasi lokal yang cukup besar dan menaungi seluruh petani tambak di Kelurahan Mangunharjo, bernama Kelompok Petani Tambak Kelurahan Mangunharjo. Kelompok Petani Tambak tersebut memiliki uang kas tersendiri dengan jumlah anggota yang cukup banyak, sehingga dapat digunakan untuk membeli lahan tambak. Selain berasal dari orang tua, masyarakat mendapat pengetahuan dalam mengelola tambak dari perkumpulan yang diadakan oleh Kelompok Petani Tambak tersebut. Jika ada permasalahan tertentu, maka biasanya petani tambak akan mengadakan pertemuan untuk membahas mengenai permasalahan tersebut dan mencari sejumlah solusi yang dapat diambil. Pertemuan tersebut digelar secara rutin dan terdapat iuran anggota, sehingga uang kasnya dapat digunakan untuk membeli lahan tambak, membangun dam dan jembatan. Akan tetapi, seiring dengan pergantian kepemimpinan, maka Kelompok Petani Tambak ini tidak memiliki manajemen pengelolaan yang baik dan pada akhirnya memutuskan untuk vakum sementara waktu.

Selanjutnya, ketika booming udang windu pada tahun 1980an, masyarakat memperoleh pengetahuan tentang pengelolaan udang windu dari pelatihan yang diadakan oleh Dinas Kelautan dan Perikanan. Setelah itu, masyarakat pun secara antusias mempraktekkan pengetahuan yang baru saja diperolehnya. Pengetahuan akan udang windu tersebut selanjutnya masih pula diasah melalui pengalaman pribadi yang dialami oleh masyarakat selama mengelola udang windu tersebut. Masyarakat belajar sendiri bagaimana mengenai kehidupan ikan dan udang dan bagaimana cara mengelola lahan tambak yang baik. Adapun, cara meneliti kualitas udang windu tersebut adalah dengan menimbang berat badan udang windu. Jika diperoleh berat badan sekitar 5 gram setelah 30-40 hari ditabur, udang windu dapat dikatakan normal. Sebaliknya, jika bobot udang windu kurang dari 5 gram, maka masih perlu diteliti lagi faktor apa saja yang mungkin menyebabkan hal tersebut, misalnya dari sisi kualitas air dan atau makanannya. Tidak hanya berasal dari masyarakat petani tambak di Kelurahan Mangunharjo, banyak orang Cina yang kemudian juga menyewa lahan tambak milik masyarakat untuk ditanami udang windu. Bahkan, perusahaan supplier udang windu yang berasal dari luar daerah pun, misalnya Surabaya, juga menyewa lahan tambak dan pengelolaannya kemudian dilakukan melalui kerjasama antara masyarakat setempat yang memiliki pengetahuan memadai terhadap udang windu dan sejumlah pekerja dari perusahaan tersebut. Selanjutnya, perusahaan supplier udang windu tersebut, seperti Agung Pratama, Tambak Mas, dan Mina Agung lah yang melakukan ekspor udang windu hingga luar negeri, dimana kebanyakan pemasarannya ditujukan ke Thailand, Singapura, dan Jepang tergantung permintaan dari beberapa negara tersebut.

Pengelolaan udang windu tidak selalu berjalan dengan mulus. Pada saat udang windu mengalami stres, hanya ada sedikit masyarakat yang dapat mengatasinya. Pengetahuan yang digunakan untuk menyembuhkan udang tersebut diperoleh berdasarkan pengalaman pribadi masyarakat dengan cara yang tergolong murah. Jadi, pertama-tama masyarakat membuang air tambak dan hanya menyisakannya sedikit, kemudian mesin pompa air dihidupkan lagi untuk mengganti air tersebut. Selanjutnya, kapur dolomit dimasukkan ke dalam tambak dengan perbandingan satu petak lahan tambak diberi satu ton kapur dolomit. Akhirnya, cara tersebut berhasil menyembuhkan udang windu tersebut. Sementara, perusahaan supplier udang windu justru harus membeli obat-obatan dari Thailand dengan harga lebih dari Rp. 1.000.000,- per liternya. Pada akhirnya, pengetahuan yang diperoleh berdasarkan pengalaman tersebut ditularkan kepada petani tambak lainnya dan perusahaan supplier udang windu tersebut.

Dengan demikian, dapat dikatakan bahwa praktek langsung di lapangan lebih bermanfaat dibandingkan dengan teori yang dimiliki, tanpa memandang tingginya tingkat 
pendidikan masyarakat. Tingkat pendidikan hingga kesarjanaan sama sekali tidak menjamin bahwa dia mampu mengelola tambak lebih baik daripada petani tambak. Pengetahuan yang dimiliki oleh petani tambak lebih banyak dan juga lebih berpengalaman dalam mengelola tambaknya. Hal ini terbukti dari hasil produksi lahan tambak yang dikelola oleh masyarakat yang memperoleh kesarjanaan lebih sedikit dibandingkan dengan petani tambak, dimana 10.000 bibit ikan bandeng pada lahan 3 hektar hanya mendapatkan 2 kuintal selama 4 bulan pengelolaan.

Selain berdasarkan pengalaman pribadi, masyarakat juga mengikuti seminar tentang pengelolaan udang windu. Seminar tersebut tidak hanya berasal dari dalam negeri, tetapi juga ada yang dari luar negeri. Seminar ini digunakan untuk meningkatkan pengetahuan masyarakat dalam mengelola udang windu. Dengan demikian, pengetahuan yang didapatkan tidak hanya berputar-putar di antara masyarakat petani tambak di Kelurahan Mangunharjo, tetapi juga telah melibatkan pihak luar.

Pasca booming udang windu, terjadi penurunan produksi lahan tambak di Kelurahan Mangunharjo dikarenakan lahan terlalu dieksploitasi demi mengejar ekonomi semata, yang ditambah pula dengan terjadinya abrasi yang ikut andil dalam menghilangkan lahan tambak milik masyarakat. Sejak saat itu, berbagai pihak mulai memberikan sejumlah perhatian dan pemikiran mengenai cara-cara apa saja yang sebaiknya ditempuh untuk kembali memulihkan perekonomian masyarakat. Pihak yang dimaksud tersebut, meliputi instansi pemerintah (terutama BLH Kota Semarang, BLH Provinsi Jawa Tengah, serta Dinas Kelautan dan Perikanan), instansi swasta (terutama CSR dari PT. Djarum), sekolahsekolah dan perguruan tinggi, baik perguruan tinggi negeri maupun swasta. Sementara, LSM yang diketahui ikut berkecimpung di Kelurahan Mangunharjo adalah LSM Biota dan LSM Bintari.

Pertama kali, proses transfer pengetahuan yang berasal lembaga-lembaga tersebut berusaha ditularkan kepada masyarakat dalam bentuk pertemuan-pertemuan tertentu. Dengan adanya pertemuan tersebut, maka diharapkan lembaga dapat mengetahui kebutuhan masyarakat Kelurahan Mangunharjo dengan tepat untuk kemudian ditindaklanjuti, misalnya dengan melalui penyuluhan dan pemberdayaan masyarakat. Penyuluhan tersebut, meliputi penyuluhan tentang pengelolaan bandeng, manfaat dan pentingnya pohon mangrove, selain terdapat pula pemberdayaan masyarakat, misalnya pembuatan bandeng presto, pembuatan ikan panggang, pelatihan menjahit, pembuatan bakso ikan, kerupuk udang, dan lain sebagainya.

Dinas Kelautan dan Perikanan sendiri bahkan memberikan pelatihan mengenai pengelolaan hasil tambak, berupa pengelolaan ikan bandeng dan kepiting, agar hasilnya lebih maksimal ketika akan dijual. Pada mulanya, petani tambak tidak mengetahui bagaimana memperlakukan bandeng pascapanen. Akan tetapi, setelah dilakukan pelatihan, maka petani menjadi memahami bagaimana mengelola bandeng agar tubuh ikan bandeng tidak kendor, sehingga harga jualnya tidak menurun. Selain itu, ada pula studi banding yang dilakukan ke Madura dan Gresik untuk melihat bagaimana mengelola lahan tambak secara optimal. Tujuan dilakukannya studi banding tersebut adalah untuk mengetahui aspek mana saja dari pengelolaan lahan tambak yang bisa dikembangkan dan kemudian dicoba ditiru untuk diterapkan di Kelurahan Mangunharjo.

Pada pasca booming udang windu ini, mulai muncul pula kelompok-kelompok kecil yang peduli terhadap lingkungan. Kelompok-kelompok kecil ini kemudian berupaya untuk menyelamatkan lingkungan dengan dukungan dari pihak pemerintah. Kelompok tersebut, meliputi Kelompok Bumi Lestari yang bergerak di bidang budidaya mangrove, Kelompok Mina Karya Utama yang bergerak di bidang pengolahan hasil tambak, seperti budidaya kepiting, Kelompok Petani Tambak Subur Makmur yang bergerak di bidang pengelolaan dan budidaya tambak, serta Kelompok Karya Mina Mandiri yang beranggotakan sejumlah wanita untuk mengolah hasil dari pohon mangrove, misalnya membuat kue dan pudding 


\section{Lesson Learned Peralihan Mata Pencaharian Masyarakat Sebagai Ketahanan Terhadap Perubahan Iklim}

mangrove. Dalam hal ini, proses transfer pengetahuan dilakukan di dalam kelompok. Anggota kelompok yang dipilih untuk menghadiri pelatihan menyalurkan ilmu yang diperolehnya kepada anggota kelompok lainnya. Jadi, ilmu yang didapatkan tidak hilang begitu saja di tengah jalan.

Bahkan, kadangkala anggota kelompok lokal di Kelurahan Mangunharjo juga bersifat gabungan, dimana kelompok petani yang berada di Kelurahan Mangkang Wetan bergabung dengan Kelurahan Mangunharjo, karena masing-masing jumlah anggota kelompok tergolong hanya sedikit. Kerjasama yang dilakukan antarpetani tambak biasanya terkait dengan pengelolaan sistem pengairan yang baik, pertemuan terutama untuk menanggulangi abrasi, serta dalam hal pengajuan bantuan kepada instansi pemerintah melalui pengajuans proposal.

Berikut ini merupakan kronologis proses pembelajaran masyarakat petani tambak di Kelurahan Mangunharjo yang ditampilkan ke dalam diagram.

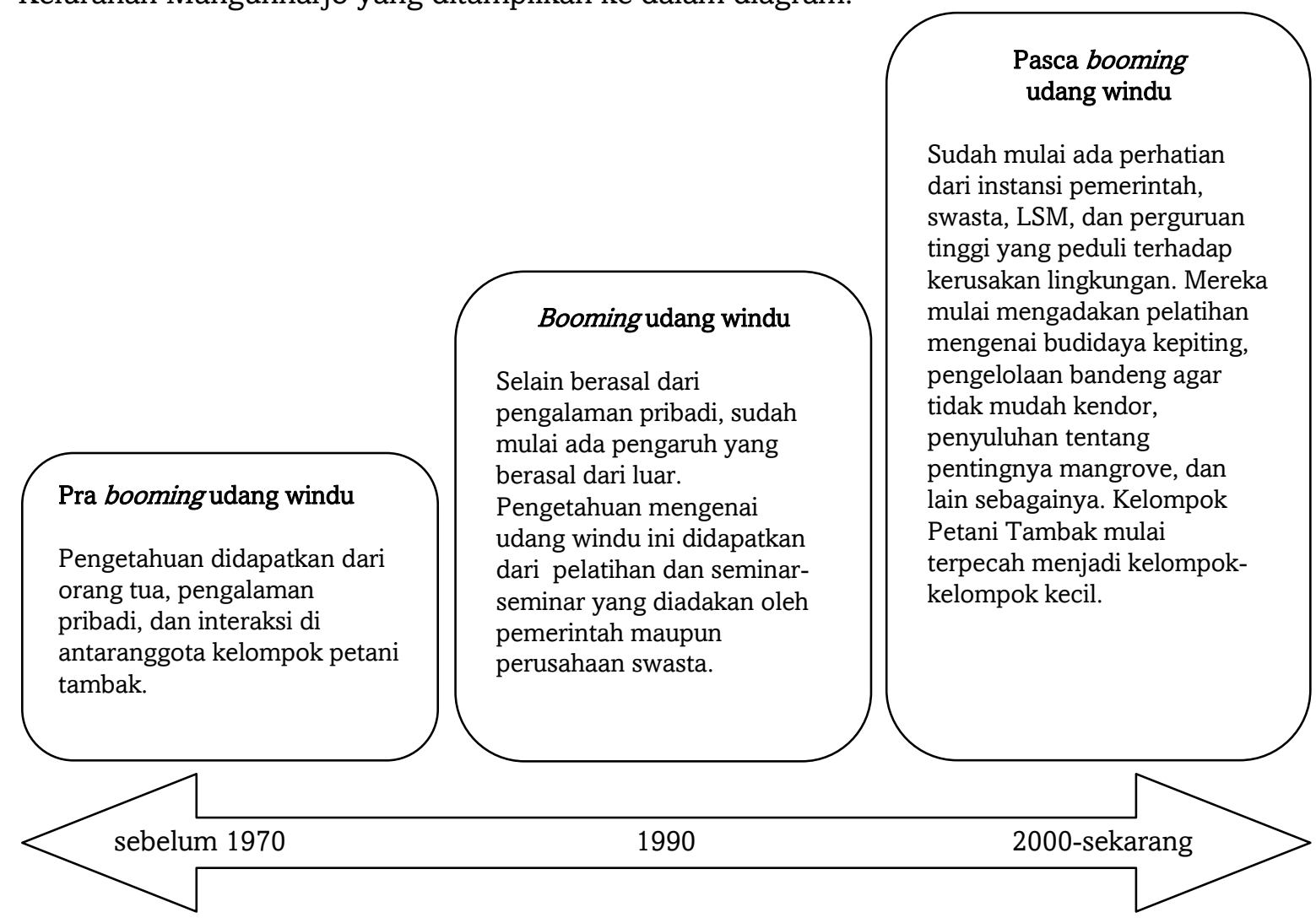

Gambar 3. Kronologis Proses Pembelajaran Masyarakat Petani Tambak di Kelurahan Mangunharjo

\section{Masyrakat yang Memutuskan Beralih Mata Pencaharian}

Masyarakat yang sepenuhnya melakukan peralihan mata pencaharian adalah masyarakat yang kehilangan lahan tambaknya karena terkena abrasi karena lahan tambaknya berada di pinggir laut, dan tidak memiliki mata pencaharian sampingan lain yang dapat diandalkan. Setelah lahan tambak yang menjadi mata pencaharian utamanya hilang terkena abrasi, maka mau tidak mau masyarakat harus melakukan peralihan mata pencaharian sebagai usaha untuk tetap mempertahankan keberlangsungan hidupnya. Berdasarkan hasil wawancara yang telah dilakukan, ada sebagian masyarakat yang berpendapat bahwa setelah lahan tambaknya hilang, mereka memperoleh manfaat dari adanya peralihan mata 
pencaharian yang dilakukan, yaitu dapat digunakan untuk menghidupi keluarga dan menyekolahkan anak.

Ada dua karakteristik masyarakat yang melakukan peralihan mata pencaharian, yaitu masyarakat yang masih bergantung kepada alam dan masyarakat yang memilih untuk tidak lagi bergantung kepada alam. Pertama, masyarakat yang masih bergantung kepada alam pada umumnya mengalihkan mata pencahariannya sebagai pembibit pohon mangrove. Hal ini didasarkan atas banyaknya permintaan (demand) bibit pohon mangrove, baik dari lembaga pemerintah, perguruan tinggi, atau lembaga swasta untuk ditanam di tepi pantai Kelurahan Mangunharjo. Oleh karena harus mengalihkan mata pencahariannya, maka masyarakat tidak lagi memperoleh pengetahuan dari orang tua atau keluarga. Masyarakat mempelajari sendiri bagaimana cara melakukan pembibitan pohon mangrove, sehingga dapat dikatakan bahwa pengetahuan pembibitan diperoleh dari pengalaman selama menjadi pembibit. Jadi, dalam hal ini, biji dari pohon mangrove (goul) jatuh ke dalam tanah dan kemudian menjadi anakan. Kemudian, anakan tersebut dimasukkan ke dalam polybag yang telah diisi dengan tanah dan diletakkan ke dalam bedeng pembesaran. Selain pengalaman pribadi, ada pula peran dari hasil interaksi dengan masyarakat yang berada dari daerah lain, seperti Rembang, instansi pemerintah dan swasta, serta sekolah dan perguruan tinggi. Masyarakat Kelurahan Mangunharjo dididik menjadi kader lingkungan oleh Badan Lingkungan Hidup (BLH) hingga sekarang sudah bisa mandiri. Pengalaman menjadi pembibit juga berasal dari perusahaan swasta. Jadi, pada awal mulanya masyarakat diajak bekerjasama dengan perusahaan swasta dan kemudian diajari bagaimana cara melakukan pembibitan yang baik. Ada juga studi banding untuk melihat tanaman mangrove yang ada di daerah lain. Studi banding tersebut dilakukan untuk melihat tanaman mangrove di daerah Pemalang dan Tegal.

Untuk pembelajaran mengenai pengembangan silvofishery sendiri, ternyata masyarakat tidak membaca buku, tetapi justru berdasarkan atas pengalaman di lapangan dengan masyarakat petani di Jaringan Petani Pantura (JPP) mulai dari Brebes hingga Rembang yang rata-rata juga mengembangkan silvofishery. Pengalaman di lapangan berawal ketika masyarakat melakukan pembibitan pohon mangrove dalam bedeng-bedeng yang juga ditanami bibit udang dan bandeng. Ketika bibit masih ada, maka hasil dari ikan dan bandeng tergolong bagus, tetapi saat bibit mangrove habis terjual, maka ikan dan udangnya menjadi stres dan tidak lama kemudian mati. Berdasarkan hal tersebut, masyarakat menyimpulkan bahwa pohon mangrove memiliki banyak manfaat, terutama untuk meningkatkan produktivitas hasil tambak. Selain pengalaman pribadi dan interaksi antarpetani tambak, pernah ada pelatihan mengenai silvofishery yang diberikan oleh Dinas Kelautan dan Perikanan selama 3-5 kali pertemuan. Akan tetapi, hasil dari penerapan pelatihan tersebut tidaklah maksimal, karena praktek langsung di lapangan ternyata sangat berbeda dengan teori yang diberikan. Jika teori mengatakan ukuran batasan tertentu, pada kenyataannya, ukuran tersebut tidak dapat dipraktekkan di lapangan. Jadi, pada akhirnya masyarakat mencoba mencari sendiri ukuran yang cocok untuk pengembangan silvofishery.

Berdasarkan atas penjelasan di atas, maka dapat dirinci lagi bahwa jenis mata pencaharian masyarakat Kelurahan Mangunharjo dapat dibedakan berdasarkan atas sektor primer dan sektor sekunder. Mata pencaharian yang termasuk ke dalam sektor primer merupakan mata pencaharian yang masih mengandalkan sumberdaya alam, sementara mata pencaharian yang termasuk ke dalam sektor sekunder merupakan mata pencaharian yang telah melibatkan tingkat sumberdaya manusia dan tidak mengandalkan alam. Masingmasing dari sektor tersebut tentu saja memiliki proses transfer pengetahuan yang berbeda.

Berikut ini merupakan gambar proses pembelajaran mata pencaharian masyarakat di Kelurahan Mangunharjo yang dirangkum ke dalam sebuah bagan. (lihat Gambar 4) 


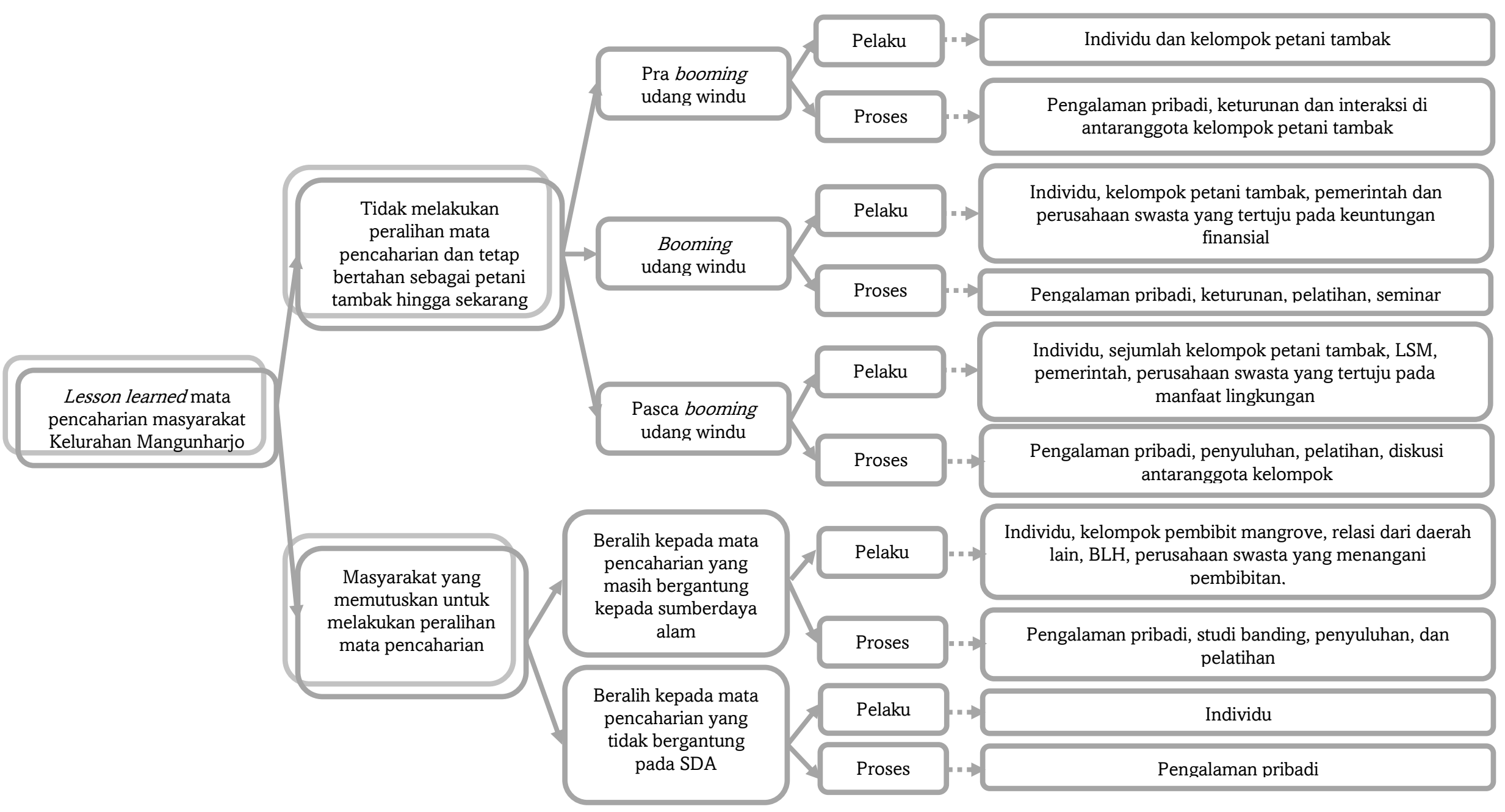

Gambar 4. Proses Pembelajaran Mata Pencaharian Masyarakat di Kelurahan Mangunharjo 


\section{Tiara Citra Septiana 137}

\section{a. Sektor primer}

Pada mata pencaharian yang termasuk ke dalam sektor primer, maka tranfer pengetahuan pertama kali diperoleh dari orang tua ataupun keluarga. Masyarakat yang menggeluti mata pencaharian di sektor primer ini adalah petani tambak. Pada saat produktivitas lahan tambak masih tinggi, masyarakat petani tambak dapat mencukupi kebutuhan hidupnya hingga tingkat kebutuhan tersier, misalnya untuk naik haji. Akan tetapi, setelah produksi lahan tambak jauh berkurang seperti saat ini, masyarakat di Kelurahan Mangunharjo justru berada dalam taraf bertahan hidup (survival) untuk mencukupi kebutuhan sehari-hari dan keluarga. Ada sebagian masyarakat yang kemudian melakukan peralihan mata pencaharian, tetapi tetap masih bergantung kepada alam, yaitu sebagai pembibit pohon mangrove. Dalam hal ini, proses transfer pengetahuan tidak lagi berasal dari orang tua atau keluarga, tetapi lebih kepada pengalaman, pelatihan, dan interaksi antarindividu dalam menggeluti mata pencaharian tersebut. Mata pencaharian sebagai pembibit pun masih berada pada tahapan survival, yaitu masih sekedar memenuhi kebutuhan hidup keluarga sehari-hari.

b. Sektor sekunder

Pada sektor sekunder dimana mata pencaharian sudah mengandalkan tingkat sumberdaya manusia, maka transfer pengetahuan tidak lagi diperoleh dari orang tua ataupun keluarga. Misalnya, buruh, dimana mereka memperoleh 1 kali gaji dan mereka selalu berpikir bagaimana mencukupkan penghasilan tersebut selama 1 bulan, sehingga masyarakat pun masih berada dalam taraf bertahan hidup. Jika memiliki mata pencaharian sampingan sekalipun, maka mata pencaharian tersebut hanya cukup akan digunakan untuk memenuhi kebutuhan hidup primer dan sekunder, dan belum mampu memenuhi kebutuhan hidup tersier. Selanjutnya, ada pula tingkatan yang dapat diketahui dalam menggeluti mata pencaharian pada sektor sekunder, hal ini dapat ditemui dari responden yang bergerak di sektor isi ulang galon. Pada awalnya, tingkatannya hanya masyarakat itu sendiri yang mengusahakan air galon isi ulang, misalnya mengantarkan dan memasarkan sendiri pesanan air galon. Kemudian, pada tingkat selanjutnya, beberapa tahun kemudian, usaha yang dilakukannya dapat mengalami peningkatan, yaitu saat ini sudah memiliki 2 orang karyawan yang bertugas mengantarkan galon. Jadi, masyarakat tersebut sudah tidak perlu bekerja, karena sudah memiliki tenaga kerja yang dapat diandalkan. Hal ini menandakan bahwa terdapat peningkatan status ekonomi masyarakat dari usaha yang digelutinya sekarang.

\section{Kesimpulan dan Rekomendasi}

Kendala yang masih terjadi hingga saat ini terletak pada proses transfer pengetahuan yang dimiliki oleh masyarakat. Pada saat masih menjadi petani tambak, pengetahuan dalam pengelolaan lahan tambak diwariskan secara turun menurun dari orang tua atau keluarga. Akan tetapi, ketika lahan tambak tidak lagi produktif, masyarakat menjadi kebingungan untuk mengalihkan mata pencahariannya kepada bentuk mata pencahariannya yang lain. Akibatnya, kebanyakan masyarakat beralih kepada pekerjaan yang tidak membutuhkan tingkat pendidikan dan tingkat keterampilan yang tinggi, misalnya dengan bekerja sebagai ojek, penjual minyak wangi, penjual air isi ulang, dan lain sebagainya. Namun, ada pula masyarakat yang beralih menjadi pembibit mangrove, dimana dalam hal ini transfer pengetahuan tidak lagi berasal dari orang tua, tetapi justru dari pihak pemerintah yang memberikan sejumlah pelatihan serta pengalaman pribadi dari masing-masing individu. Terkait dengan peluang ke depan, maka proses pembelajaran ini dapat direplikasi ke daerah lainnya. 


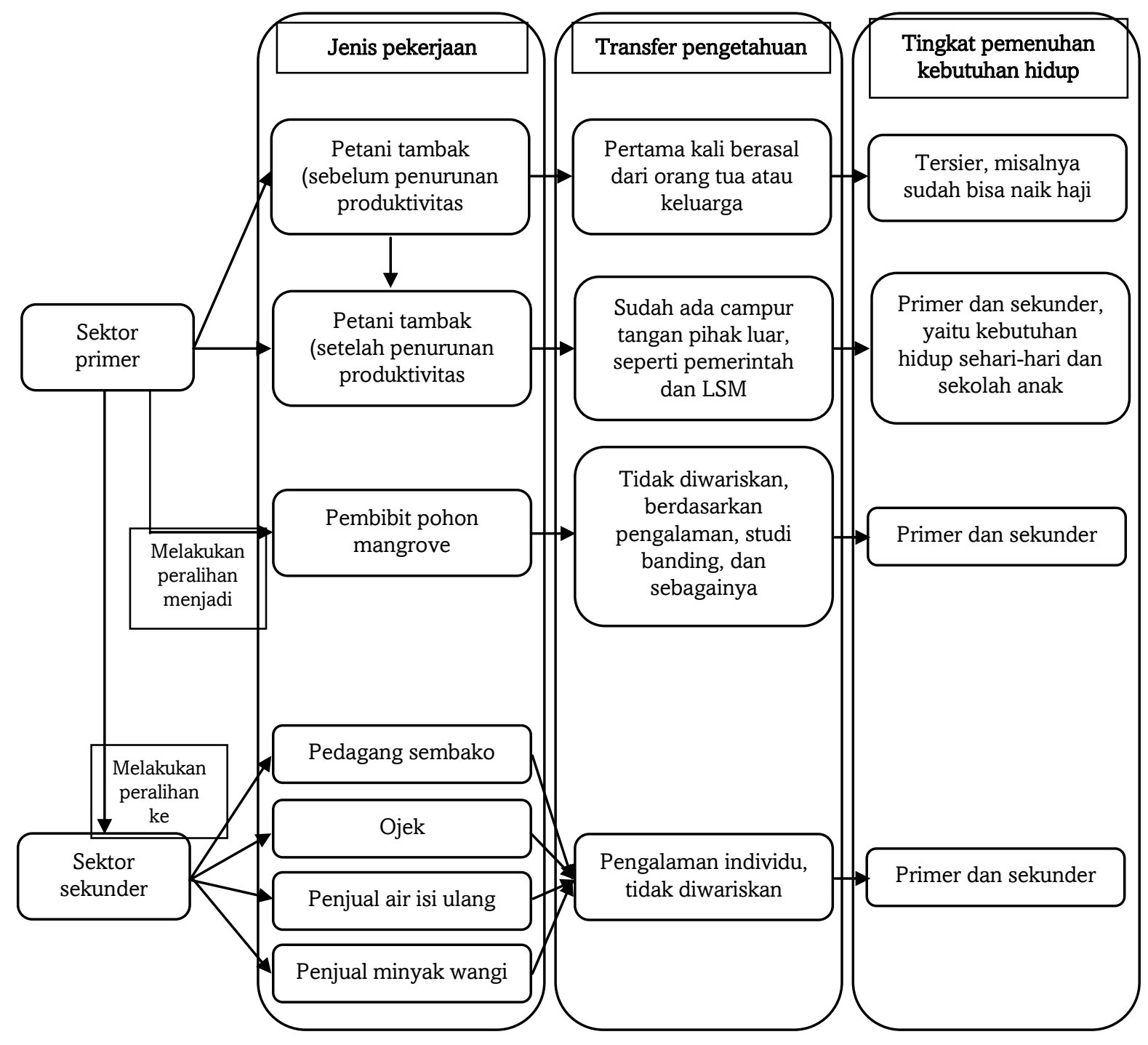

\section{Gambar 5. Jenis Mata Pencaharian Masyarakat Kelurahan Mangunharjo Dirinci Menurut Sektor Primer dan Sektor Sekunder Beserta Proses Transfer Pengetahuan dan Tingkat Pemenuhan Kebutuhan Hidup Masyarakat}

Ada sejumlah rekomendasi yang dapat diberikan untuk meningkatkan ketahanan sosial dan ekonomi masyarakat terkait dengan proses peralihan mata pencaharian di Kelurahan Mangunharjo. Rekomendasi tersebut ditujukan bagi masyarakat Kelurahan Mangunharjo, instansi pemerintah, beserta LSM yang ikut berkecimpung di kelurahan tersebut.

Adapun, rekomendasi yang dapat diberikan kepada masyarakat Kelurahan Mangunharjo, antara lain sebagai berikut:

a. Membuka peluang kerjasama kelompok masyarakat Mangunharjo dengan kelompok masyarakat di kawasan pesisir wilayah lain, sehingga masyarakat dapat memperoleh pengetahuan baru, misalnya dengan melalui studi banding, yang kemudian dapat digunakan untuk meningkatkan produksi lahan tambak di Kelurahan Mangunharjo. Kendala terbesar masyarakat dalam mengembangkan usahanya adalah keterbatasan modal dan pemasaran. Oleh karena itu, lembaga keuangan sebaiknya mampu memberikan pinjaman dana bagi masyarakat yang membutuhkan dengan bunga yang 
terjangkau. Lembaga keuangan seharusnya menaruh kepercayaan terhadap masyarakat Kelurahan Mangunharjo dalam hal pengembalian dana pinjaman tersebut. Selain itu, pemerintah pun membantu pemasaran produk yang dihasilkan oleh masyarakat, sehingga masyarakat mampu memiliki jalur pemasaran tertentu.

a. LSM tetap memberikan bantuan, berupa penyuluhan dan pelatihan, dan penanaman mangrove secara berkesinambungan, sehingga kondisi kerusakan lingkungan tidak semakin bertambah parah setiap tahunnya.

b. LSM memberikan pemberdayaan masyarakat Kelurahan Mangunharjo, misalnya dalam pelatihan pembuatan kue mangrove dan kemudian juga membantu dalam pemasaran dari kue mangrove tersebut.

\section{Daftar Pustaka}

ACCRN dan Mercy Corps. 2010. Penilaian Kerentanan Berbasis Masyarakat Semarang Dan Bandar Lampung. Indonesia.

Data Monografi Kelurahan Mangunharjo 2010. Kantor Kelurahan Mangunharjo.

Dinas Kelautan dan Perikanan. 2010. Pemetaan Potensi, Kerusakan, dan Model Rehabilitasi Kawasan Pesisir Kota Semarang. Semarang.

Few, Roger. 2003. Flooding, Vulnerability And Coping Strategies: Local Responses To A Global Threat. Progress in Development Studies: Sage Publications.

International Institute for Environment and Development (IIED). 2010. Developing Local Climate Change Plans. UN-Habitat Cities in Climate Change Initiative.

IPCC, Working Group II. 2007. Fourth Assessment Report Climate Change 2007: Climate Change Impacts, Adaptation and Vulnerability.

Kecamatan Tugu dalam Angka 2008.

OECD. 2001. Innovation, Learning and Regions In The Knowledge-Based Economy. Cities and Regions in The New Learning Economy. OECD Publications Service: Paris.

Rockwell Foundation. 2010. “Asian Cities Climate Change Resilience Network (ACCCRN),” dalam Rockefeller Foundation http://www.rockefellerfoundation.org/what-we-do/current-work/developing-climatechange-resilience/asian-cities-climate-change-resilience/. 
140 Lesson Learned Peralihan Mata Pencaharian Masyarakat Sebagai Ketahanan Terhadap Perubahan Iklim 